\title{
Asymmetric myocardial thickening in aortic stenosis
}

\author{
Calvin W Chin, Emily N Yeung, Anoop S Shah, Scott Semple, Maria Koo, Nicholas Mills, David Newby, \\ Marc R Dweck
}

From 18th Annual SCMR Scientific Sessions

Nice, France. 4-7 February 2015

\section{Background}

Asymmetric wall thickening has been observed in aortic stenosis (AS) but the clinical importance is poorly understood. We hypothesized this pattern was associated with advanced remodeling and worse outcomes.

\section{Methods}

Left ventricular volumes, wall thickness and mass were assessed in 166 patients (70 [64, 76] years; 69\% males) with cardiovascular magnetic resonance. Diffuse myocardial fibrosis was assessed using myocardial T1

\begin{tabular}{|c|c|c|c|}
\hline & $\begin{array}{c}\text { Concentric wall } \\
\text { thickening } \\
(n=69)\end{array}$ & $\begin{array}{c}\text { Asymmetric wall } \\
\text { thickening } \\
(n=43)\end{array}$ & $P$ value \\
\hline \multicolumn{4}{|l|}{ BASELINE CHARACTERISTICS } \\
\hline Age, years & $70[64,77]$ & $72[67,75]$ & 0.41 \\
\hline Males, n (\%) & $54(78)$ & $31(72)$ & 0.60 \\
\hline Coronary artery disease, $\mathrm{n}(\%)$ & $22(32)$ & $20(47)$ & 0.18 \\
\hline Hypertension, n (\%) & $48(70)$ & $33(77)$ & 0.54 \\
\hline Systolic blood pressure, $\mathrm{mmHg}$ & $150 \pm 20$ & $153 \pm 22$ & 0.46 \\
\hline \multicolumn{4}{|l|}{ ECHOCARDIOGRAPHY } \\
\hline Peak aortic jet velocity, $\mathrm{m} / \mathrm{s}$ & $3.9[3.4,4.5]$ & $4.2[3.9,4.9]$ & $<0.01$ \\
\hline Mean pressure gradient, $\mathrm{mmHg}$ & $35[24,44]$ & $41[35,50]$ & $<0.01$ \\
\hline Aortic valve area, $\mathrm{cm}^{2}$ & $0.82[0.70,1.08]$ & $0.80[0.66,0.98]$ & 0.18 \\
\hline \multicolumn{4}{|c|}{ CARDIOVASCULAR MAGNETIC RESONANCE } \\
\hline $\begin{array}{l}\text { Indexed end diastolic volume (EDV), } \\
\mathrm{mL} / \mathrm{m}^{2}\end{array}$ & $67[60,74]$ & $68[62,78]$ & 0.19 \\
\hline Indexed end systolic volume, $\mathrm{mL} / \mathrm{m}^{2}$ & $22[16,26]$ & $22[18,26]$ & 0.50 \\
\hline Indexed stroke volume, $\mathrm{mL} / \mathrm{m}^{2}$ & $44[40,52]$ & $47[41.55]$ & 0.26 \\
\hline Ejection fraction, \% & $68[64,72]$ & $67[64,73]$ & 0.93 \\
\hline $\begin{array}{l}\text { Indexed left ventricular mass (LVMi), } \\
\mathrm{mg} / \mathrm{m}^{2}\end{array}$ & $92[82,103]$ & $96[80,106]$ & 0.50 \\
\hline LVMi/EDVi (mg/mL) & $1.33[1.23,1.56]$ & $1.36[1.21,1.50]$ & 0.50 \\
\hline
\end{tabular}

Figure 1 Baseline characteristics of patients with concentric and asymmetric wall thickening. 


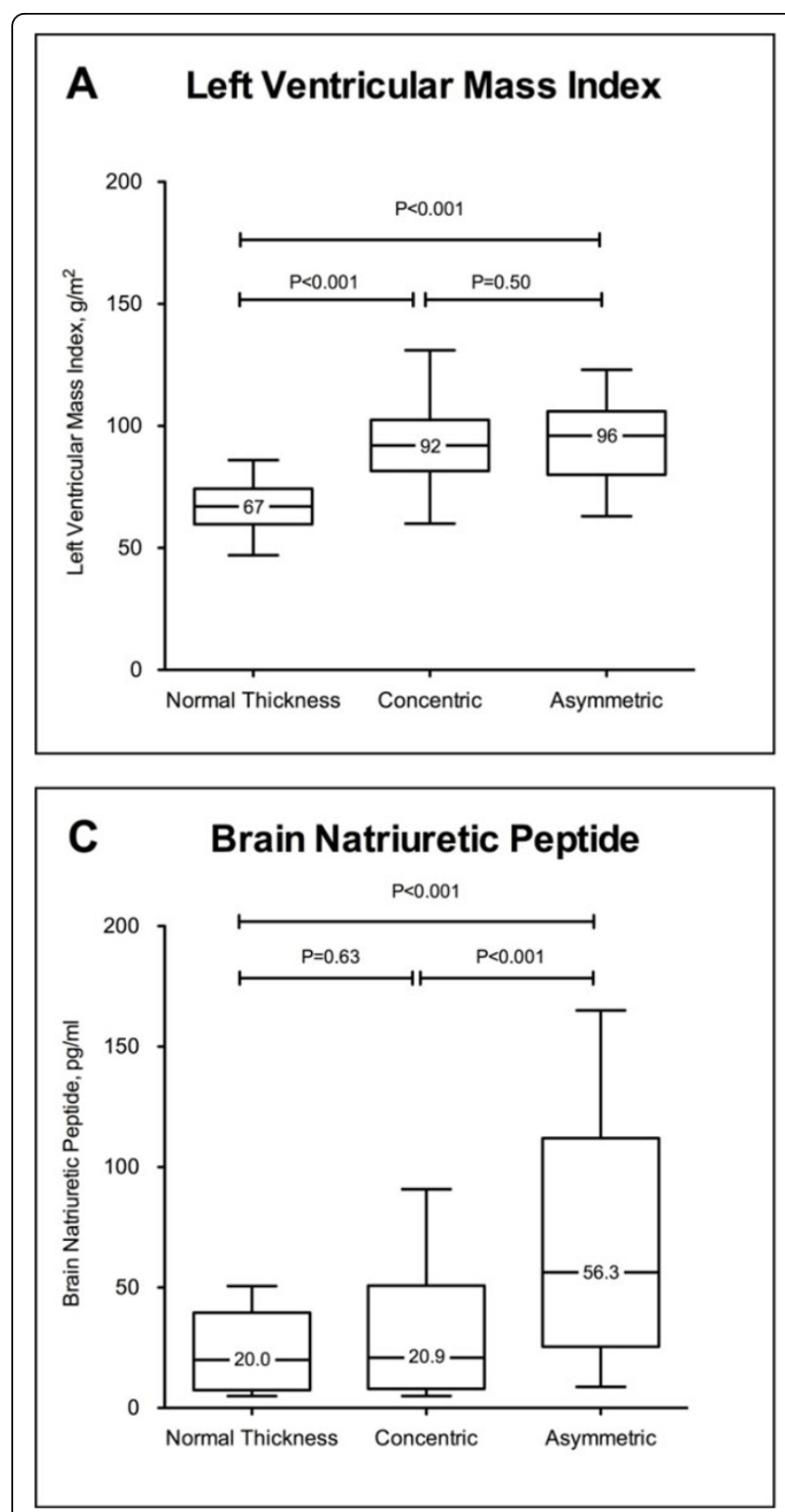

\section{B High Sensitivity Troponin I}
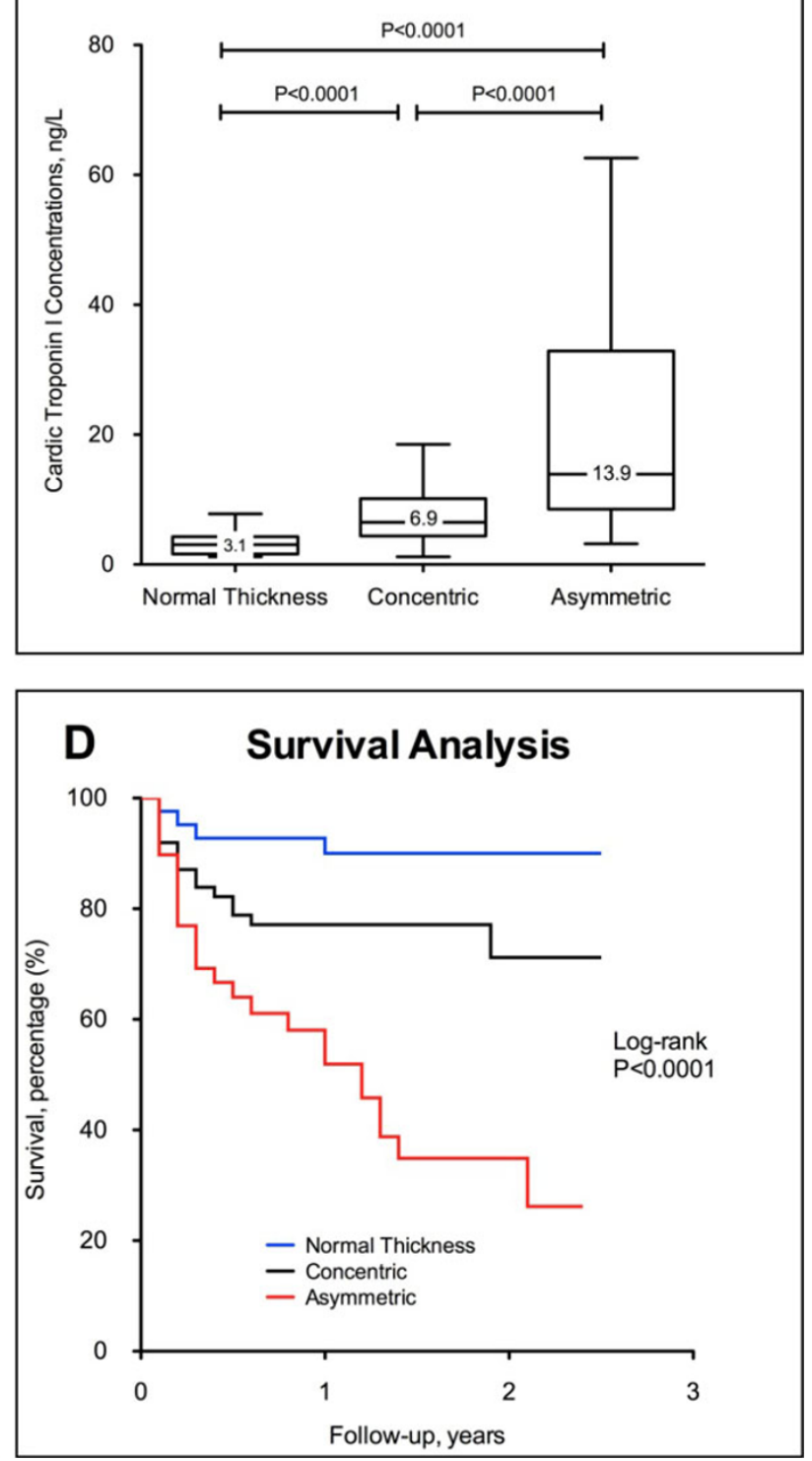

Figure 2 Compared to patients with concentric wall thickening, patients with asymmetric wall thickening had smilar left ventricular mass index (A) but elevated high-sensitivity troponin I (B) and brain natriuretic peptide concentrations (C). Importantly, patients with asymmetric wall thickening had worst outcomes compared to those with normal and concentric wall thickening (D).

mapping (partition coefficient, $\lambda$ ). In the absence of infarction, asymmetric wall thickening was defined as myocardial thickness $\geq 13 \mathrm{~mm}$ and opposing wall thickness ratio $\geq 1.5$. High-sensitivity cardiac troponin I (cTnI) and brain natriuretic peptide (BNP) concentrations were used as markers of myocardial injury and decompensation, respectively. Aortic valve replacement and all-cause mortality were assessed at 1 year.

\section{Results}

Compared to patients with concentric wall thickening $(n=69)$, those with asymmetric pattern $(n=43)$ had increased diffuse myocardial fibrosis $(\lambda$ values $0.48 \pm 0.04$ versus $0.46 \pm 0.04$, respectively; $\mathrm{P}=0.04$ ) despite similar age, sex, systolic blood pressure (SBP), and left ventricular mass index (LVMi; Table 1 and Panel A; all $\mathrm{P}>0.10$ ). Plasma cTnI and BNP concentrations were also increased independent of age, sex, SBP, AS severity and LVMi (both $\mathrm{P}<0.01$; Panels $\mathrm{B}$ and $\mathrm{C}$ ). Patients with 
asymmetric pattern had worst outcomes compared to those with concentric thickening and normal wall thickness (log-rank $\mathrm{P}<0.0001$; Panel D).

\section{Conclusions}

In aortic stenosis, asymmetric wall thickening is associated with ventricular decompensation and a worse prognosis.

\section{Funding}

The study is supported by the British Heart Foundation.

Published: 3 February 2015

doi:10.1186/1532-429X-17-S1-Q49

Cite this article as: Chin et al:: Asymmetric myocardial thickening in aortic stenosis. Journal of Cardiovascular Magnetic Resonance 201517 (Suppl 1):Q49.

Submit your next manuscript to BioMed Central and take full advantage of:

- Convenient online submission

- Thorough peer review

- No space constraints or color figure charges

- Immediate publication on acceptance

- Inclusion in PubMed, CAS, Scopus and Google Scholar

- Research which is freely available for redistribution

Submit your manuscript at www.biomedcentral.com/submit 